Elżbieta Rydz*

Czestaw Walesa**

Matgorzata Tatala***

\title{
Structure and Level of Religiosity Test
}

\begin{abstract}
The aim of the article is to present a new measure of structure and level of religiosity. The cognitivedevelopmental concept of integral development of religiosity by Czestaw Walesa, which distinguishes eight parameters of religiosity: religious awareness, religious feelings, religious decisions, bond with the fellowship of believers, religious practices, religious morality, religious experience and forms of profession of faith served as the theoretical bases for the test. The measure was constructed to fit the specificity of the people of the Christian profession. The preliminary reliability and validity indicators were calculated on 126 participants. Construct validity was established with Centrality of Religiosity Scale (C-15), Scale of Religious Identity, Deconversion Scale for Adolescents. The psychometric indicators were satisfactory, which shows that the test can be used to measure structure and level of style of religiosity.
\end{abstract}

Key words: development of religiosity, measure of structure and level of religiosity

\section{Introduction}

The article presents a method based on a cognitivedevelopmental concept of integral development of religiosity to measure its structure and level. In order to study the structure of religiosity, theoretically distinguished parameters (domains) are necessary. Structure and Level of Religiosity Test (SLRT) has two advantages: it provides the measure of these parameters as well as the overall level of religiosity in an individual.

The theoretical premises of the test allow to interpret parameters of religiosity in the context of stages of religiosity development, which, by C. Walesa, are: (1) pre-religious period ( $0-1$ years of age); (2) first manifestations of religiosity (2-3 years of age); (3) magic religiosity (3.5-6.5 years of age); (4) authoritative-moral religiosity (7-11 years of age); (5) forming of autonomous religiosity (12-17 years of age); (6) religious authenticity (18-24 years of age); (7) realistic and stable religiosity (25-39 years of age); (8) fulfilled religiosity (40-60 years of age); (9) religiosity of people growing old (60 years of age and more). The domains of functioning are: (1) biotic; (2) cognitive; (3) emotional; (4) motivational; (5) social; (6) decision; (7) moral; (8) identity; (9) psychosexual;
(10) professional; (11) esthetic; (12) worldvie; (13) functioning in the reality formed by culture (mainly by the media).

The SLRT is based on a holistic theory of religiosity which postulates that religiosity permeates both periods of development and individual domains of functioning. Religiosity operationalized in the presented paper has an autotelic character, but the test is of instrumental nature, as it serves theoretical, scientific and practical purposes.

\section{Theoretical bases of the test construction}

The cognitive-developmental concept of integral development of religiosity by Czesław Walesa served as the bases for the construction of the test.

\section{Walesa's theory in comparison to other theories of religiosity development}

Psychologists of this trend base their concepts mainly on developmental theories of Piaget and Kohlberg. To mention a few, they are: (1) stages of faith development (Fowler, 1981); (2) development of understanding of the language of religion (Goldman, 1964); (3) development of thinking and religious identity (Elkind, 1970); (4) religious

\footnotetext{
* The John Paul II Catholic University of Lublin

** University of Economics and Innovation in Lublin

*** The John Paul II Catholic University of Lublin 
judgement theory (Oser \& Gmünder, 1991); (5) cognitivedevelopmental concept of integral development of religiosity (Walesa, 1997, 1998, 2005). Walesa (1997, 1998, $2005,2008)$ uses the following definition of religiosity: religiosity is a personal and positive relation of person towards God, which is expressed in experiences, processes and mental states (Walesa, 2005, p. 13).

Religiosity is an integral and homogeneous phenomenon, even though it has many aspects and is visible through specific manifestations of mental and socio-cultural functioning. Religious development is in general autotelic, transformational and transgressive, but the transcending may be vertical or/and horizontal, encompassing different and equivalent domains. Walesa describes periods and phases of religious development by referring to the works of Piaget. The first three parameters correspond to three interrelated mental spheres: cognition (cognitive, information and orientation processes), attitude (emotional and motivational processes) and action (decision and performance processes). They are assigned to three domains (parameters) in the structure of religiosity: (1) religious awareness, (2) religious feelings and (3) religious decisions. The next three parameters were distinguished from understanding religiosity as a socio-cultural phenomenon, and they are: (4) bond with the fellowship of believers, (5) religious practices, and (6) religious morality. The last two parameters were singled out through metric and content analysis of religiosity, as a global manifestation of self; they are: (7) religious experience and (8) forms of profession of faith.

Distinguishing theses parameters does not exhaust the knowledge on the complexity of the structure of religiosity. The epigenetic approach proposes that religiosity is studied from simple quasi-religious, to more complex forms, which go beyond the average in this aspect of life (e.g. in the masters of spiritual life). Hence, the author differentiates additional secondary and tertiary parameters.

The parameter of religious awareness includes: (1) cognitive expression of the relations towards God, as mental representations of religious acts; (2) religious understanding, which is composed of memory (ability to store and reconstruct effects of experiences) and evaluative thinking (which selectively manages the experiences); (3) determining religious character of the components of consciousness; (4) acquiring religious sense through participation or communication with significant believers (acquiring sense deepened by being a part of a fellowship of believers).

The parameter of religious feelings means: (1) determining religious feelings through the components: quality (positive or negative), intensity with evaluative estimation, object of feelings, (personal and positive relation of person towards God), stimulation to behaviors religious in character; (2) types of religious feelings experienced at three levels: basic (separate and unique feelings significantly different from each other, as e.g. the feeling of joy and fear), superior (related to events which facilitate or hinder achieving the superior goal, which is the closest relation with God, and subordinate (feelings referring to specific religious situations and life conditions); (3) identifying and naming religious feelings; (4) informative function of religious feelings, which point at favorable or unfavorable meaning of events for the relation with God.

Parameter of religious decisions concerns the freedom sphere and includes: everyday decisions, meta-decisions, planning of the future and directing one's freedom towards God. The components of religious decisions are: (1) structure and religiosity of the decision; (2) taking existential risks; (3) meta-decisions often concerning vocation, which, according to Walesa, indicate religious maturity; (4) preferences, choices and decisions which show grounding of the principles of religious life; (5) full religious decision, constituting personal and positive relation to God.

Bond with the fellowship of believers, as a parameter expressing the psychosocial aspect of religiosity refers to various social circles, such as family or people representing the institution of the Church: clergy, catechists and other people participating at the liturgical life of the Church. The characteristics of this complex parameter include: (1) a platform of religious experiences of the community of believers, whose essence is in constant contact with Sacrum. The platform, especially during prayer, defines the system of situations, roles, rules of behavior, functions, communication, language, as well as understanding of the meanings and symbols; (2) laws and duties, needs and calls aimed at the members of religious community as well as some rules of its functioning; (3) participation in the life of the community of believers; (4) types of bond with the fellowship of believers which shape both the religiosity of a person and their extra-religious activity, and (5) importance and regulatory power of the bond with the fellowship of believers.

Religious practices is a parameter describing the consequential dimension of human religiosity, the level of present functioning, next to skills and abilities. It includes: (1) religious practices as the effect of cooperation and coordination of processes and components of religiosity; (2) competences concerning the participation in the activities of the community: willingness and ability of being and taking action together, achieving common goals, as well as communication competences of religious character; (3) types of religious practices which depend on the level of development of religious consciousness, morality, type of religious motivation and way of fulfilling the bond with the fellowship of believers. Among the latter, the author distinguishes practices: spontaneous or forced, authentic or conformist, associated with joy or anxiety, giving momentum and expression or hindering them; (4) religious practices as rites, cultural activities. The parameter may be evaluated in terms of importance and regulatory power.

The parameter of religious morality is a domain in which religious attitudes of morality, such as criteria of good or evil, religious arguments for fairness or unfairness of behaviors, and motives for taking action, are most important. Detailed knowledge of religious morality 
involves: (1) the relationship between rules of religious morality with rules resulting from a personal relation to God; (2) functions; (3) structure of religious morality; (4) structure of consciousness, and (5) regulatory and indicatory power of religious morality. The primary source of regulatory power of morality is religious awareness and bond with the fellowship of believers. Its consequential character needs to be included as well (Walesa, 2005, p. 36).

Religious experience is difficult to present in terms of verbal, terminological and scientific explanation. It is overall experience with components of cognition, orientation, information, emotions, decisions and expression, concerning a personal and direct relation with the supernatural reality, and connected with the conviction of certainty, obviousness and truthfulness of what the person experiences with their intentional and positive relation to God, and its consequences (Walesa, 2005, p. 39). The religious experience grows from faith and sense of reality. Formal analysis shows how different spheres of mental functioning shape the religious experience, determining its different styles. In turn, content analysis involves: experiencing God's presence (immanence or transcendence), God's action, vocation (calling) and experiencing God's attributes.

Forms of profession of faith is a parameter of a substantial religious character, as opposed to the other seven psychological parameters. It is generally referred to as life inspired by faith, actions driven by it and its personal character. Profession of faith is displayed by: (1) understanding and expressing a religious nature of events; (2) readiness for prayer and sacrifice, and (3) religious mystery. This parameter is considered to be a sensitive indicator of religiosity, showing its regulatory, integrating and boosting power, especially when religious believes are expressed in border situations, when the most important values are tested.

The described parameters were distinguished on the basis of studies and theoretical reflection, in the context of current psychological concepts of religiosity. Their purpose is to order and interpret results of research. They can indicate the level of religiosity, even though indicatory power of particular parameters is not equally high: religious awareness is considered the lowest, and religious experience - the highest in indicating individual level of religiosity. Basic parameters do not encompass the entirety of the phenomenon of religiosity. With the expansion of studies on the topic, secondary and tertiary parameters, such as religious language, experience of religious beauty and many more, should also be included. Through the parameters of the structure of religiosity it is possible to analyze the effects of changes in religiosity development in particular spheres (religious awareness, religious feelings, religious decisions and the others). The results of religiosity development have different qualitative and quantitative ranges. Religious engagement, as the central quality of an individual which is also reflected in their general development, is an important issue. In its light, the problem is not only how religiosity develops, but also how it organizes the general human development (Walesa, 2005, p. 68).

The presented concept analyses factors of religiosity development, their types and effects on shaping religiosity at different life stages. The factors are: (1) endogenic regulations (inborn capabilities, development, adolescence); (2) external developmental factors (surroundings, upbringing, learning, and introducing to the principles of religious life); (3) coordination and balance factors (own activity, accidental events, exceeding limitations and transcending towards Sacrum); (4) meta-factors of development, such as logics or fairness of own activity, general ability to live a life of faith, realistic perception of the reality and ability to function in the world of different "selves", meta-cognition, fundamental dynamisms of forming own "self" in relation to others (Walesa, 2005, p. 71-77).

Awareness of the changes in own religiosity challenges a religious person to discover a more optimal development of other spheres. The author of the concept proposes that religiosity of an adult cannot be a model of child religiosity, it is a separate and autonomous system.

The empirical studies on religiosity in a lifetime in the cognitive-developmental perspective are generally based on qualitative methods. For research purposes standardized questionnaires based on explorative interviews by Piaget were created (see Walesa, 2005; Tatala, 2006, 2008; Piątek, 2008; Rydz, 2012).

\section{Construction of the test}

The first stage of the construction of the test was the creation of statements which relate to the distinguished parameters of religiosity (religious awareness, religious feelings, religious decisions, bond with the fellowship of believers, religious practices, religious morality, religious experience and forms of profession of faith). Construction of the items started with a detailed content analysis of the theoretical premises, research review (Rydz, 2012; Piątek, 2008; Tatala, 2006) as well as theological knowledge (e.g. The Catechism of the Catholic Church) for each parameter. 279 items were constructed in the year 2014 . By the means of expert analysis (the author of the theory and two experienced researchers of the concept) 176 items were chosen. With thise version of test 289 people were examined.

On the bases of factor analysis 40 items with the highest congruence indicators $(N=289)$, five items per parameter, were distinguished. The items are formulated as affirmatives and negatives (20 of each). There are eight subscales measuring eight parameters of religiosity: religious awareness, religious feelings, religious decisions bond with the fellowship of believers, religious practices, religious morality, religious experience and forms of profession of faith. The participants rate the statements on a five-point scale which corresponds to the compatibility with the items (I agree completely/ I agree / I agree sometimes, but sometimes I disagree / I disagree / I disagree completely), presence of the issues expressed 
in the items in the life of the participant (It definitely concerns me / It concerns me / It concerns me sometimes and sometimes it does not concern me / It does not concern me / It does not concern me at all), frequency of a behavior expressed by the item (very often/ often / sometimes/ rarely / never).

Items in the parameter of religious awareness:

1. God knows what is useful for me.

2. Knowledge of religion does not help me solve problems.

3. I think that God is not interested in people.

4. Faith does not help me understand the meaning of life.

5. Demands of the Church make my life in the contemporary world difficult.

Items in the parameter of religious feelings:

6. Suffering of the Christ evokes the feelings of mercy in me.

7. I feel confidence when I think about Last Judgement.

8. When God ignores my prayers, I rebel against Him.

9. I feel that God does not love me.

10. In the face of difficulties I stop trusting in God.

Items in the parameter of religious decisions:

11. When making important decisions, I seek advice of deeply religious people.

12. When making important decisions I ask myself about the ultimate goals in my life.

13. I am not satisfied with how God's plans are fulfilled in my life.

14. I think that God is helping me even when I'm making a bad decision.

15. When life ruins my plans I ask myself about the ultimate goals in my life.

Items in the parameter of bond with the fellowship of believers:

16. I want to preach the Gospel.

17. I reckon that no one may be a sole believer.

18. I deepen my Christian knowledge in the fellowship of believers.

19. Thanks to participating in the life of the community of believers, I changed significantly.

20. I give important religious information to others.

Items in the parameter of religious practices:

21. Respect I have for my parents results from my faith.

22. I do not seek to spend Sunday in a Christian way.

23. I do not pray for the dead.

24. I observe the Christian ways of celebrating holidays.

25. I do not observe fasting demanded by the Church.

Items in the parameter of religious morality:

26. I solve my own personal dilemmas without consulting the preaching of the Church.

27. I do not accept the position of the Church in relation to some moral issues.

28. In my life I follow the Ten Commandments.
29. When I experience moral difficulties I do not ask fellow believers for advice.

30. I do not feel ashamed in the face of God when I break moral rules.

Items in the parameter of religious experience:

31. I experience that everything is a gift from God.

32. I do not entrust God with my problems.

33. I do not entrust God with my life.

34. Even at the Church I do not experience a bond with Jesus Christ.

35. I do not experience closeness with God.

Items in the parameter of forms of profession of faith:

36. I spread the cult of God's mercy through my own life.

37. My behavior is a consequence of my living faith.

38. In difficult life situations I do not express my faith.

39. In the events of my life I do not cooperate with God enough.

40. The feeling of mystery revives my relations with God.

Scores of the items allow for a description of the levels and styles of religiosity in adolescents and adults. The studies were conducted in 2014-2015. Reliability and validity of the test was measured with the participation of 126 people at the age range of 18 to 25 . Stability was checked using the test-retest method on the group of 70 participants with a two-week interval. Descriptive statistics are presented in Table 1.

Table 1. Descriptive statistics of the SLRT

for the overall score and the eight parameters of religiosity $(N=126)$

\begin{tabular}{lll}
\hline $\begin{array}{c}\text { Parameters of religiosity } \\
\text { in the SLRT }\end{array}$ & $\boldsymbol{M}$ & $\boldsymbol{S D}$ \\
\hline religious awareness & 11.62 & 4.27 \\
\hline religious feelings & 13.87 & 2.81 \\
\hline religious decisions & 13.98 & 3.07 \\
\hline $\begin{array}{l}\text { bond with the fellowship } \\
\text { of believers }\end{array}$ & 16.20 & 4.61 \\
\hline religious practices & 11.58 & 4.50 \\
\hline religious morality & 13.92 & 4.41 \\
\hline religious experience & 13.15 & 3.69 \\
\hline forms of profession of faith & 15.29 & 3.58 \\
\hline
\end{tabular}

\subsection{Reliability of the SLRT}

Internal consistency Cronbach's $\alpha$

Analyzing statistic properties of the items and looking for internal consistency, it is possible to learn about the reliability of both the subscales and the whole test. The higher the value of the coefficient, the more homogenous the items (Hornowska, 2001, p. 53; Zarzycka, 2007, p. 146). The value of the Cronbach's alpha coefficient 
Elżbieta Rydz, Czesław Walesa, Małgorzata Tatala

for the overall score (sum of the scores of the subscales) was $.947(N=126)$, which shows a high reliability of the measure. For the particular subscales, Cronbach's $\alpha$ coefficients were:

.839 religious awareness,

.361 religious feelings,

.483 religious decisions,

.874 bond with the fellowship of believers,

.776 religious practices,

.801 religious morality,

.660 religious experience,

.748 forms of profession of faith.

According to the classification of Weise (1975, quoted by Zarzycka, 2007) and Linert and Raat (1998, quoted by Zarzycka, 2007), the reliability coefficients for the subscales of religious awareness, bond with the fellowship of believers, and religious morality, are high, and for religious practices, forms of profession of faith, religious decisions they are satisfactory to assess individual differences. The results obtained in the parameter of religious feelings should be interpreted with greater caution.

\subsection{Stability of the SLRT}

Stability indicator for the overall score in the interval of two weeks was .951, $N=70$, and for the particular subscales it ranged from .665 to $.887(p=.01)$. The obtained correlations between measurement time 1 and 2 confirmed the stability of the scale. The highest values were found for the overall score (.951), bond with the fellowship of believers (.885), religious practices (.887), and religious awareness (.859). The parameter of religious decision was found to have the lowest value (.665).

Table 2. Stability of the SLRT in a two-week interval $(N=70)$

\begin{tabular}{lc}
\hline \multicolumn{1}{c}{ Parameters of SLRT } & $t$ \\
\hline overall score & $.951^{* *}$ \\
\hline religious awareness & $.859^{* *}$ \\
\hline religious feelings & $.719 * *$ \\
\hline religious decisions & $.665^{* *}$ \\
\hline bond with the fellowship of believers & $.885^{* *}$ \\
\hline religious practices religijne & $.887 * *$ \\
\hline religious morality & $.829 * *$ \\
\hline religious experience & $.830^{* *}$ \\
\hline forms of profession of faith & $.764 * *$ \\
\hline$* * p<.01$ &
\end{tabular}

\subsection{Validity of the SLRT}

The indicator of validity of a test is the degree in which it reflects the measured psychological trait (Hornowska, 2001). Internal consistency indicators of the parameters ranged from .664 to .888 .
Table 3. Pearson's $r$ correlation between the overall score and the parameters $(N=126)$

\begin{tabular}{lc}
\multicolumn{1}{c}{$\begin{array}{c}\text { Parameters of religiosity } \\
\text { SLRT }\end{array}$} & $\begin{array}{c}\text { Overall score } \\
\text { of the SLRT } \boldsymbol{r}\end{array}$ \\
\hline religious awareness & $.888^{* *}$ \\
\hline religious feelings & $.664^{* *}$ \\
\hline religious decisions & $.737^{* *}$ \\
\hline $\begin{array}{l}\text { bond with the fellowship } \\
\text { of believers }\end{array}$ & $.828^{* *}$ \\
\hline religious practices & $.840^{* *}$ \\
\hline religious morality & $.839^{* *}$ \\
\hline religious experience & $.842^{* *}$ \\
\hline forms of profession of faith & $.884^{* *}$ \\
\hline
\end{tabular}

$* * p<.01$

\section{Construct validity}

Construct validity of the measure was calculated by correlating it with Centrality of Religiosity Scale (C-15, Huber, 2003), Scale of Religious Identity (Wieradzka-Pilarczyk, 2015) and Deconversion Scale for Adolescents (Nowosielski and Bartczuk, 2016).

Firstly, the analyses were conducted for the SLRT and Centrality of Religiosity Scale C-15, they are presented in Table 4. The overall score for Centrality of Religiosity Scale is the sum of scores in five subscales: ideology, prayer, experience, worship and cognitive interest. Together they are the measure of centrality of religiosity which is the autonomy of religious constructs in comparison to all the systems of the person (Zarzycka, 2007).

Positive strong correlations were expected between the overall score of the SLRT and centrality, religious awareness and centrality, bond with the fellowship of believers, centrality and worship, religious practices and worship, religious morality, centrality and worship, religious experience and experience $\mathrm{C}-15$ as well as forms of profession of faith, centrality and worship.

Significant correlations between C-15 and SLRT were obtained. The highest correlations were found between the overall score of the SLRT and centrality (.892) and interest (.837). Religious awareness is related to centrality (.803) and worship (.732), bond with the fellowship of believers is related to centrality (.806) and worship (.791), religious practices was found to correlate with centrality (.752) and worship (.724), religious morality is related to centrality (.704) and worship (.686), religious experience correlated with centrality (.707) and experience $\mathrm{C}-15$ (.678), forms of profession of faith are linked with centrality $(.800)$ and worship (.718), which confirms the theoretical premises. The lowest correlation values were found in the parameters of religious feelings and religious decisions, which shows that they are separate constructs, not measured by the $\mathrm{C}-15$.

Table 5 shows correlations between the SLRT and Scale of Religious Identity (Wieradzka-Pilarczyk, 2015). Wieradzka-Pilarczyk defines religious identity as inner 
Table 4. Pearson's $r$ correlations between the SLRT and Centrality of Religiosity Scale C-15 $(N=124)$

\begin{tabular}{|c|c|c|c|c|c|c|}
\hline$r$ & centrality & interest & ideology & prayer & experience & worship \\
\hline overall score & $.892 * *$ & $.837 * *$ & $.746 * *$ & $.688 * *$ & $.709 * *$ & $.541 * *$ \\
\hline religious awareness & $.803 * *$ & $.487 * *$ & $.671 * *$ & $.628 * *$ & $.657 * *$ & $.732 * *$ \\
\hline religious feelings & $.592 * *$ & $.296 * *$ & $.516^{* *}$ & $.433 * *$ & $.519 * *$ & $.569 * *$ \\
\hline religious decisions & $.636 * *$ & $.379 * *$ & $.439 * *$ & $.458 * *$ & $.645 * *$ & $.585^{* *}$ \\
\hline $\begin{array}{l}\text { bond with the fellowship } \\
\text { of believers }\end{array}$ & $.806 * *$ & $.592 * *$ & $.602 * *$ & $.595 * *$ & $.602 * *$ & $.791 * *$ \\
\hline religious practices & $.752 * *$ & $.320 * *$ & $.667 * *$ & $.635^{* *}$ & $.612 * *$ & $.724 * *$ \\
\hline religious morality & $.704 * *$ & $.492 * *$ & $.494 * *$ & $.555 * *$ & $.549 * *$ & $.686^{* *}$ \\
\hline religious experience & $.707 * *$ & $.374 * *$ & $.590 * *$ & $.526^{* *}$ & $.678 * *$ & $.622 * *$ \\
\hline forms of profession of faith & $.800 * *$ & $.545^{* *}$ & $.633 * *$ & $.623 * *$ & $.648 * *$ & $.718 * *$ \\
\hline
\end{tabular}

$* * p<.01$

auto-identification with supernatural reality created by the person in the dynamic process of individual integration as well as social image of religiosity. Forming of identity is based on dynamic and overlapping processes of (1) exploration and (2) commitment (engagement).

Positive correlations between the SLRT and the dimensions: exploration in depth, commitment making and identification with commitment were expected. The performed analyses confirmed that there are positive relationships between the overall score of the SLRT and exploration in depth (.590), commitment making (.625) as well as identification with commitment (.878). The highest correlations were obtained for identification with commitment, which shows accepting and fulfilling the decisions related to religious auto-identification (ranging from .609 in the parameter of religious feelings to .832 for religious awareness).

The SLRT was also correlated with Deconversion Scale for Adolescents. Nowosielski and Bartczuk (see Streib et al., 2009) propose that deconversion processes are all the changes in personal religiosity which are expressed by leaving the present ways of experiencing and showing religiosity (Nowosielski and Bartczuk, 2015). The results are presented in Table 6 .

Negative correlations between the parameters of the SLRT and the dimensions of Deconversion Scale for

Table 5. Pearson's $r$ correlations between the SLRT and Scale of Religious Identity $(N=118)$

\begin{tabular}{lccccc}
\hline \multicolumn{1}{c}{$\boldsymbol{c}$} & $\begin{array}{c}\text { exploration } \\
\text { in breadth }\end{array}$ & $\begin{array}{c}\text { exploration } \\
\text { in depth }\end{array}$ & $\begin{array}{c}\text { ruminative } \\
\text { exploration }\end{array}$ & $\begin{array}{c}\text { commitment } \\
\text { making }\end{array}$ & $\begin{array}{c}\text { identification } \\
\text { with commitment }\end{array}$ \\
\hline overal score SLRT & -.080 & $.590^{* *}$ & .020 & $.625^{* *}$ & $.878^{* *}$ \\
\hline religious awareness & -.075 & $.517^{* *}$ & -.042 & $.662^{* *}$ & $.832^{* *}$ \\
\hline religious feelings & -.064 & $.504^{* *}$ & $.186^{*}$ & $.444^{* *}$ & $.609^{* *}$ \\
\hline religious decisions & .013 & $.484^{* *}$ & .001 & $.467^{* *}$ & $.691^{* *}$ \\
\hline $\begin{array}{l}\text { bond with the } \\
\text { fellowship of } \\
\text { believers }\end{array}$ & -.092 & $.495^{* *}$ & -.094 & $.584^{* *}$ & $.780^{* *}$ \\
\hline religious practices & -.053 & $.499^{* *}$ & .170 & $.439^{* *}$ & $.660^{* *}$ \\
\hline religious morality & -.159 & $.545^{* *}$ & .017 & $.535^{* *}$ & $.780^{* *}$ \\
\hline religious experience & -.081 & $.490^{* *}$ & .061 & $.516^{* *}$ & $.789^{* *}$ \\
\hline $\begin{array}{l}\text { forms of profession } \\
\text { of faith }\end{array}$ & .044 & $.474^{* *}$ & -.117 & $.583^{* *}$ & $.769^{* *}$ \\
\hline
\end{tabular}

$* p<.05, * * p<.01$ 
Table 6. Pearson's $r$ correlations between the parameters of the SLRT and the subscales of the Deconversion Scale for Adolescents $(N=126)$

\begin{tabular}{|c|c|c|c|c|c|c|c|}
\hline$r$ & $\begin{array}{c}\text { intellectual } \\
\text { doubt }\end{array}$ & $\begin{array}{l}\text { emotional } \\
\text { suffering }\end{array}$ & $\begin{array}{c}\text { loss } \\
\text { of religious } \\
\text { experience }\end{array}$ & $\begin{array}{c}\text { moral } \\
\text { criticism }\end{array}$ & $\begin{array}{l}\text { leaving the } \\
\text { community }\end{array}$ & $\begin{array}{c}\text { weakening } \\
\text { in seeking } \\
\text { information }\end{array}$ & $\begin{array}{l}\text { overall score } \\
\text { deconversion }\end{array}$ \\
\hline religious awareness & $-.509 * *$ & $-.259 * *$ & $-.559 * *$ & $-.647 * *$ & $-.469 * *$ & $-.595 * *$ & $-.665^{* *}$ \\
\hline religious feelings & $-.278^{*}$ & -.024 & $-.271^{*}$ & $-.366^{* *}$ & $-.297 *$ & $-.275^{*}$ & $-.336^{*}$ \\
\hline religious decisions & $-.378 * *$ & -.187 & $-.378 * *$ & $-.516^{* *}$ & $-.363 * *$ & $-.416^{* *}$ & $-.492 * *$ \\
\hline $\begin{array}{l}\text { bond with } \\
\text { the fellowship } \\
\text { of believers }\end{array}$ & $-.382 * *$ & -.250 & $-.456^{* *}$ & $-.613 * *$ & $-.541 * *$ & $-.569 * *$ & $-.629 * *$ \\
\hline religious practices & $-.323 *$ & -.179 & $-.424 * *$ & $-.577 * *$ & $-.344 * *$ & $-.301 *$ & $-.466 * *$ \\
\hline religious morality & $-.374 * *$ & -.143 & $-.411 * *$ & $-.619 * *$ & $-.525^{* *}$ & $-.538 * *$ & $-.587 * *$ \\
\hline religious experience & $-.549 * *$ & -.233 & $-.551 *$ & $-.574 * *$ & $-.416^{* *}$ & $-.427 * *$ & $-.594 * *$ \\
\hline $\begin{array}{l}\text { forms of profession } \\
\text { of faith }\end{array}$ & $-.541 * *$ & $-.314^{*}$ & $-.520 * *$ & $-.546 * *$ & $-.464 * *$ & $-.485 * *$ & $-.625^{* *}$ \\
\hline overal score SLRT & $-.499 * *$ & -.243 & $-.539 * *$ & $-.679 * *$ & $-.522 * *$ & $-.551 * *$ & $-.668 * *$ \\
\hline
\end{tabular}

$* p<.05, * * p<.01$

Adolescents were expected. This was confirmed: every correlation was found to be negative. Emotional suffering was found to be significantly related to the parameters of religious awareness and forms of profession of faith.

\section{Conclusions}

The article presented a measure of the operationalization of the theory of religiosity development. The results of the studies on the reliability and validity of the SLRT showed that the presented version is a useful tool to analyze religiosity in the aspects of its level, structure and styles.

The results of the presented study suggest that there are correlations between the SLRT and other measures of religiosity: Centrality of Religiosity Scale (C-15, Huber, 2004), Scale of Religious Identity by (Wieradzka-Pilarczyk, 2014) and Deconversion Scale for Adolescents (Nowosielski and Bartczuk, 2015). Novelty of the tool lies in a possibility of estimating the level of religiosity in its parameters, as well as distinguishing its individual styles e.g. style concentrated on the aspect of religious awareness (cognitive style), religious feelings (feeling style), religious decisions (decision-action style), bond with the fellowship of believers (style concentrated on living in a community), religious morality (style concentrated on the moral aspect of religious life), and many others.

It seems that the main advantage of the article is presenting the methods of arriving at the results. It involves describing the parameters, and consequently the structure of religiosity (structural definition). Furthermore, theoretical and practical application of the tool is interesting.
Presenting a holistic approach to religiosity adjusted to the stages of development and domains of functioning is a theoretical contribution of the paper. Moreover, a detailed description of styles of religiosity is another forte, especially when literature review shows that this issue has been absent in the field. The focus of this article has not been placed on practical applications, however, the authors invite the readers to use the test in research, diagnostic and educational purposes, self-diagnosis, and religious selfeducation. It is worth to mention that even though the SLRT is used mainly with people whose religiosity develops in a normal way, it can also help in the diagnosis of different deficits in the development of religiosity as well as in supporting its growth.

To conclude, the work on the SLRT is starting rather than finishing. The measure will be improved as it is used in research with different age groups, stages of development and when analysed in the context of various human behaviors.

\section{References}

Allport, G. (1988). Osobowość i religia. Warszawa: PAX.

Amoura, C., Berjot, S., Gillet, N., Caruana, S., Cohen, J., \& Finez, L. (2015). Autonomy-supportive and controlling styles of teaching. Opposite or distinct teaching styles? Swiss Journal of Psychology, 74, 141-158.

Barkin, S.H., Miller, L., \& Luthar, S. (2015). Filling the void: Spiritual development among adolescence of the affluent. Journal of Religion and Health, Vol. 54(3), 844-861.

Czerwińska-Jasiewicz, M., \& Zagórska, W. (2007). Developmental psychology: New theoretical concepts and research directions. Polish Psychological Bulletin, 115-117.

De Cruz, H. (2013). Religious concepts as structured imagination. The International Journal for the Psychology of Religion, 24, 63-74. 
Elkind, D. (1970). The origin of the religion in the child. Review of Religious Research, 12, 35-42.

Erikson, E. (2004). Tożsamość a cykl życia. Poznań: Zysk i S-ka.

Fowler, J. (1981). Stages of faith: the psychology of human development and the quest for meaning. New York: Harper and Row.

Goldmann, R. (1964). Religious thinking from childhood to adolescence. London: Routledge and Kegan.

Grzymała-Moszczyńska, H. (1991). Psychologia religii. Wybrane zagadnienia. Karaków: Nomos.

Hardy, S.A., White, J.A., Zhang, Z., \& Ruchty, J. (2011). Parenting and the Socialization of Religiousness and Spirituality. Psychology of Religion and Spirituality, 3, 217-230.

Huber, S. (2004). Zentralität und multidimensionale Struktur der Religiosität: Eine Synthese der theoretischen Ansätze von Allport und Glock zur messung der Religiosität. In C. Zwingmann, H. Moosbrugger (Eds.), (pp. 79-105). Religiosität: Messverfahren und Studien zu Gesundheit und Lebensbewältigung. Neue Beiträge zur Religionpsychologie. Münster/New York/München/Berlin: Waxmann

Huston, J.D., Todd, N.R. (2013). Religious congregation and social justice participation: A multilevel examination of social process and leadership. American Journal of Community Psychology, 52, 273-287.

Kielar-Turska, M. (2011). Kształtowanie się naukowej psychologii rozwoju człowieka. In J. Trempała (Eds.), (pp. 3-28). Psychologia rozwoju czlowieka. Podręcznik akademicki. Warszawa: Wydawnictwo Naukowe PWN.

Kohlberg, L. (1976). Moral stage and moralization: The cognitive-developmental approach. In T. Lickona (Eds.), Moral development and behavior: New York: Holt.

Luyckx, K., Goossens, L., Soenens, B., \& Beyers, W. (2006). Unpacking commitment and exploration: Validation of an integrative model of adolescent identity formation. Journal of Adolescence, 29, 361-378

Luyckx, K., Schwartz, S.J., Berzonsky, M.D., Soenens, B., Vansteenkiste, M., Smits, I., \& Goosens, L. (2008). Capturing ruminative exploration: Extending the four-dimensional model of identity formation in late adolescence. Journal of Research in Personality, 42, $58-82$.

Makselon, J. (Eds.), (2002). Studia z psychologii rozwoju. Kraków: Wydawnictwo Naukowe PAT.

Marcia, J.E. (2002). Identity and psychosocial development in adulthood. Identity: An International Journal of Theory and Research, 2, 7-28.

Matczak, A. (1982). Style poznawcze. Rola indywidualnych preferencji. Warszawa: Państwowe Wydawnictwo Naukowe.

Nowosielski, M., \& Bartczuk, R. (2015). Religijność w procesie przemian - koncepcja dekonwersji H. Streiba. Studia Psychologica, 15(2), $5-21$.

Oser, F.K. (1980). Stages of Religious Judgment. In C. Brusselmans (Eds.), (pp. 227-315). Toward Moral and Religious Maturity. Morristown, $\mathrm{NJ}$.

Oser, F., \& Gmünder, P. (1992). Der Mensch - Stufen seiner religiösen Entwicklung. Ein strukturgenetischer Ansatz. Gütersloh: Mohn.

Oser, F., \& Reich, K. (1996). Psychological perspectives on religious development. World Psychology, 2, 365-396.

Paloutzian, R.F. (2005). Religious conversion and spiritual transformation: A meaning- system analysis. In R.F. Paloutzian, C.L. Park (Eds.), (pp. 331-347). Handbook of the psychology of religion and spirituality. New York. Guilford Press.

Paloutzian, R.F., Murken, S., Streib, H., \& Rößler-Namini, S. (2013) Conversion, deconversion, and spiritual transformation: a multilevel interdisciplinary view. In R.F. Paloutzian, C.L. Park (Eds.), (pp. 399-421). Handbook of the psychology of religion and spirituality ( $2^{\text {nd }}$ edition). New York: Guilford Press.

Piaget, J. (1972). Intellectual evolution from adolescence to adulthood. Human Development, 15, 1-12.

Piątek, M. (2008). Pleć a rozwój religijności. Tarnobrzeg: PWSZ im. St. Tarnowskiego.

Radoń, S. (2013). Korelaty przeżyć mistycznych młodzieży o uzdolnieniach artystycznych. Polskie Forum Psychologiczne, 18, 346-262.
Rydz, E., \& Jakimiak, M. (2007). Wielowymiarowe modele struktury religijności i metody pomiaru religijności człowieka dorosłego. Psychologia Rozwojowa, 12(3), 19-29.

Rydz, E., \& Zarzycka, B. (2008). Poziom religijności a poczucie spójności wewnętrznej w okresie młodzieńczym. Psychologia Rozwojowa, 4(13), 49-59.

Rydz, E., \& Zarzycka, B. (2008). Kompetencje społeczne a religijność osób w okresie młodej dorosłości. In E. Rydz, D. Musiał (Eds.), (pp. 65-82). Z zagadnień psychologii rozwoju człowieka. T.2. Lublin: TN KUL JPII.

Rydz, E., \& Zarzycka, B. (2009). Poczucie koherencji a struktura religijności. In H. Gasiul, E. Wrocławska-Warchala (Eds.), (pp. 370-383). Osobowość i religia. Warszawa: Wydawnictwo UKSW.

Rydz, E. (2012). Tendencje rozwojowe religijności mlodych dorostych. Lublin: Wydawnictwo KUL.

Rydz, E. (2014). Development of religiousness in young adults. In K. Adamczyk, M. Wysota (Eds.), (pp. 67-84). Functioning of young adults in a changing world, Kraków: Libron.

Streib, H., Hood, R.W., Keller B., Csöff, R.-M., \& Silver, C.F. (2009). Deconversion: Qualitative and quantitative results from cross-cultural research in Germany and the United States of America. Göttingen: Vandenhoeck, Ruprecht.

Streib, H., Hood, Jr. R.W., \& Klein, C. (2010). The Religious Schema Scale: Construction and Initial Validation of a Quantitative Measure for Religious Styles. The International Journal for the Psychology of Religion, 20, 151-172.

Tatala, M., (2008). Odbiór symboli religijnych przez młodzież. Lublin: Wydawnictwo KUL.

Tatala, M., \& Walesa C. (2010). Dynamic-energizing aspects of emotions in young people. In E. Rydz, D. Musiał (Eds.), (pp. 67-95). The psychology of human development - selected issues.

Walesa, C. (1994). Doświadczenia religijne młodzieży. In T. Ożóg (Eds.), (pp. 107-138). Nauki społeczne o młodzieży. Lublin: Norbertinum.

Walesa, C. (1996). Czynniki rozwoju religijności (analiza psychologiczna). In A. Januszewski, P. Oleś, W. Otrębski (Eds.), (pp. 41-58). Studia z Psychologii w Katolickim Uniwersytecie Lubelskim. T. 8, Lublin: RW KUL.

Walesa, C. (1997). Psychologiczna analiza zmian w rozwoju religijności człowieka. Roczniki Filozoficzne - Psychologia, 45(4), 109-132.

Walesa, C. (1998). Struktura religijności człowieka. Analiza psychologiczna. Zeszyty Naukowe KUL, 41(3-4), 3-48.

Walesa, Cz. (1999). Religijne przeżywanie piękna u młodzieży (badania rozwojowe osób w wieku od 12 do 24 lat). Roczniki Psychologiczne, 2, 55-93.

Walesa, C. (2003). Wyjaśnianie religijności człowieka (analiza psychologiczna). In P. Francuz, M. Grygielski, W. Otrębski (Eds.), (pp. 21-38). Studia z psychologii w KUL, t. 11. Lublin: Wydawnictwo KUL.

Walesa, C. (2005). Rozwój religijności czlowieka. T. 1. Dziecko. Lublin: Wydawnictwo KUL.

Walesa, C. (2006). Rozwój religijności człowieka. In S. Głaz (Eds.), (pp. 111-146). Podstawowe zagadnienia psychologii religii. Kraków: WAM.

Walesa, C. (2008). Rozwój religijności młodzieży. In Encyklopedia katolicka, t. 12. Lublin: TN KUL.

Zagórska, W. (2004). Uczestnictwo młodych doroslych w rzeczywistości wykreowanej kulturowo. Doświadczenie, funkcje psychologiczne. Kraków: Universitas.

Zagórska, W. (2010). Integration of logos and mythos as a developmental necessity. In E. Rydz, D. Musiał (Eds.), (pp. 13-27). The psychology of human development - selected issues.

Zarzycka, B. (2007). Skala Centralności Religijności S. Hubera. Roczniki Psychologiczne, 10, 1, 133-157.

Zarzycka, B. (2011). Polska adaptacja Skali Centralności Religijności S. Hubera. In M. Jarosz (Eds.), (pp. 231-261). Psychologiczny pomiar religijności. Lublin: Towarzystwo Naukowe KUL. 